\title{
Impact of Candida albicans hyphal wall protein 1 (HWP1) genotype on biofilm production and fungal susceptibility to microglial cells
}

\author{
Carlotta F. Orsi ${ }^{\mathrm{a}}$ b, Elisa Borghi ${ }^{\mathrm{a}}$, Bruna Colombari ${ }^{\mathrm{b}}$, Rachele G. Neglia ${ }^{\mathrm{b}}$, \\ Daniela Quaglino ${ }^{\mathrm{c}}$, Andrea Ardizzoni ${ }^{\mathrm{b}}$, Giulia Morace ${ }^{\mathrm{a}}$, Elisabetta Blasi ${ }^{\mathrm{b}, *}$ \\ ${ }^{a}$ Department of Health Sciences, University of Milan, Polo Universitario San Paolo, Via Di Rudinì 8 - Blocco C, $8^{\circ}$ piano, 20142 Milano, Italy \\ ${ }^{\mathrm{b}}$ Department of Diagnostics, Clinical and Public Health Medicine, University of Modena and Reggio Emilia, Via del Pozzo 71, 41124 Modena, Italy \\ ${ }^{\mathrm{c}}$ Department of Life Sciences, University of Modena and Reggio Emilia, Via Campi 287, 41125 Modena, Italy
}

\section{A R T I C L E I N F O}

\section{Article history:}

Received 3 December 2013

Received in revised form

27 February 2014

Accepted 20 March 2014

Available online 28 March 2014

\section{Keywords:}

Candida albicans

Hyphal wall protein 1 (HWP1) genotype

Biofilm

Microglial cells

\begin{abstract}
A B S T R A C T
The hyphal wall protein 1 (HWP1) gene of Candida albicans encodes for a fungal cell wall protein, required for hyphal development and yeast adhesion to epithelial cells; yet, its role in pathogenesis remains largely unknown. In the present study, we analyzed two $C$. albicans laboratory strains, the DAY286 (HWP1/HWP1) and the null mutant FJS24 (hwp1/hwp1) and six clinical isolates [3 harbouring the homozygous HWP1 gene (HWP1/HWP1) and 3 the heterologous gene (HWP1/hwp1)]. Biofilm production, fungal HWP1 mRNA levels and ultrastructural morphology were investigated; also, the susceptibility of these strains to microglial cells was evaluated, in terms of fungal damage and immune cell-mediated secretory response. When comparing the two laboratory strains, biofilm was produced to a similar extent independently on the genetic background, while the susceptibility to microglial cell-mediated damage was higher in the hwp1/hwp1 mutant than in the HWP1/HWP1 counterpart. Also, transmission electron microscopy revealed differences between the two in terms of abundance in surface adhesin-like structures, fungal cell wall shape and intracellular granules. When comparing the clinical isolates grouped according to their HWP1 genotype, reduced biofilm production and increased susceptibility to microglial cell-mediated damage occurred in the HWP1/hwp1 isolates with respect to the HWP1/HWP1 counterparts; furthermore, upon exposure to microglial cells, the HWP1/HWP1 isolates, but not the HWP1/hwp1 counterpart, showed enhanced HWP1 mRNA levels. Finally, both laboratory and clinical isolates exhibited reduced ability to stimulate TNF $\alpha$ and nitric oxide production by microglial cells in the case of heterozygous or null mutant HWP1 genotype.

Overall, these data indicate that C. albicans HWP1 genotype influences pathogen morphological structure as well as its interaction with microglial cells, while fungal biofilm production results unaffected, thus arguing on its role as virulence factor that directly affects host mediated defences.
\end{abstract}

(c) 2014 Elsevier Ltd. All rights reserved.

\section{Introduction}

Candida albicans, a commensal of human mucosa in healthy people, behaves as an opportunistic pathogen in critical patients, where it causes deep-seated life-threatening infections [1]. In particular, invasive candidiasis (IC) affects $9 \%$ of patients in the intensive care units and $2-20 \%$ of preterm newborns, with a

\footnotetext{
* Corresponding author. Department of Diagnostics, Clinical and Public Health Medicine, University of Modena and Reggio Emilia, Istituti Biologici, Via Campi 287, 41125 Modena, Italy. Tel.: +39059 205 5468; fax: +39 0592055483.

E-mail addresses: elisabetta.blasi@unimore.it, ardizzoni.andrea@unimore.it (E. Blasi).
}

mortality ranging from 20 to $50 \%$ [2,3]. Medical devices, such as cardiovascular and urinary catheters, dialysis access and ventriculoperitoneal shunts are considered to be a crucial point of entry for Candida in these clinical settings [4-6], where, though relatively rare, meningoencephalitis may also occur as a severe complication of deep-seated candidiasis [2,3,7]. To date, little is known on the events driving the onset of such deep-seated infections; increasing attention is being focused on fungal capacity to produce biofilm directly onto medical devices as a first and critical step towards host invasion [8,9].

In line with this, initial evidence indicates that biofilmproducing $C$. albicans isolates are less susceptible to host innate 


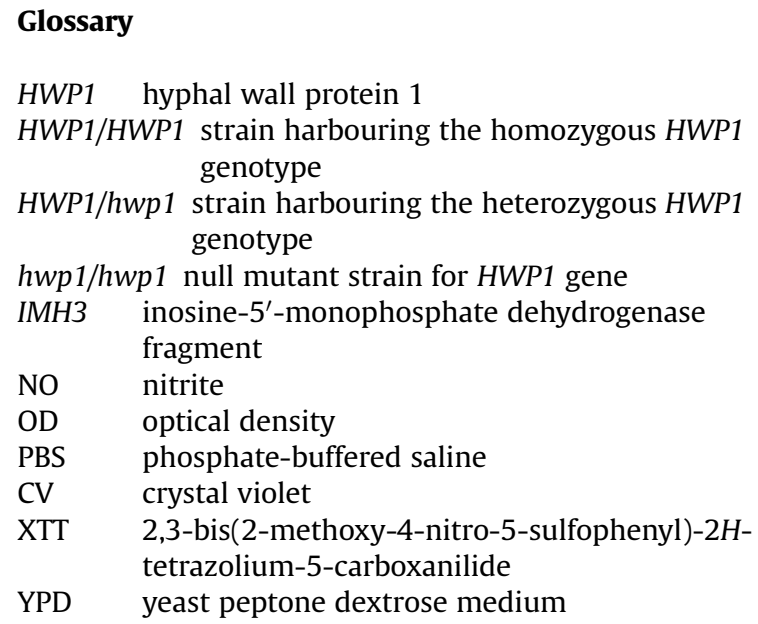

immune defences than biofilm-non producing counterparts [10,11]. Thus, biofilm formation is assumed to work as an immune escape mechanism that, in conjunction with reduced susceptibility to antifungal agents, may greatly support the persistence of implantassociated C. albicans infections [6]. Moreover, it has been recently shown that Candida biofilm can act in vitro as a reservoir of infectious viruses [12] further expanding the potential implications of fungal biofilms in clinical settings.

Numerous $C$. albicans gene products have been identified as relevant to biofilm development onto abiotic surfaces in vitro $[13,14]$, while information on genes that enable biofilm formation in vivo has begun to emerge only recently $[15,16]$. A library of C. albicans mutants, defective in specific genetic traits, has been partially screened [13]; by this approach, several genes including $B C R 1, A L S 1, A L S 3, E C E 1$ and HWP1, have been shown to be required for biofilm formation [16,17]. In particular, the gene HWP1 is known to encode a major C. albicans protein involved in several functions, including cell wall assembly, intracellular signalling and hyphal development; moreover, HWP1 promotes binding of Candida to epithelial cells, as the initial step of colonization [18-24]. Furthermore, some evidence exists on the pathogenic role of HWP1 in vivo; indeed, as assessed by a murine model of systemic candidiasis, it has been shown that the heterologous and the null mutant strains exhibit reduced and no virulence, respectively, when compared to the wild type control strain $[19,25]$.

Not only Candida, with its plethora of finely regulated virulence traits, but also the first line host defences critically impact on the onset and outcome of candidiasis. Initial studies provided relevant information on the role of brain macrophages in the control of meningoencephalitis. In particular, by a murine model of intracerebral infection, it has been shown that microglial cells exert a protective role [26], through efficient phagocytosis and antiCandida activity, whose biomolecular mechanisms have partially been defined [27-30]. Furthermore, microglial cell-mediated defences are affected by $C$. albicans peculiarities, such as the genotype profile (b versus $c$ ) and the dimorphic transition from yeast-tohyphal form [31-33].

Here, by means of two $C$. albicans laboratory strains (the reference strain DAY286 and its isogenic hwp1/hwp1 mutant, FJS24 strain) and six clinical isolates (3 harbouring the homozygous HWP1/HWP1 genotype and 3 the heterozygous HWP1/hwp1), the role of HWP1 genotype has been evaluated in terms of biofilm production and Candida-microglial cells interaction.

\section{Materials and methods}

\subsection{C. albicans}

We used two laboratory strains: the reference DAY286 (HWP1/ HWP1) and its isogenic engineered counterpart, the null mutant FJS24 (hwp1/hwp1) [13,16]; such strains were purchased from the Fungal Genetics Stock Center (Kansas City, Missouri, USA) [34]. We also used six clinical isolates of $C$. albicans, recently collected during an Italian National Survey on invasive fungal infections [35]; such isolates had been characterized according to their HWP1 gene polymorphism [36]. In particular, three isolates (lab names: Ca50vr, Ca23tv and Ca4no) harboured the homozygous genotype HWP1/ HWP1 and three isolates (laboratory names: Ca24ba, Ca48va and Ca17vr) were bearing the heterozygous genotype HWP1/hwp1. Long-term storage of the isolates was carried out in 20\% glycerol at $-80^{\circ} \mathrm{C}$. Before testing, a loopful of cells from stock cultures were inoculated in yeast peptone dextrose liquid medium (YPD, Oxoid, Hampshire, UK) and incubated overnight in an orbital shaker at $30^{\circ} \mathrm{C}$. Then, yeast cells were washed twice with sterile phosphatebuffered saline (PBS, EuroClone, Wetherby, UK), counted and suspended in medium at the desired concentration $\left(10^{5}\right.$ or $10^{6}$ cells/ $\mathrm{ml})$.

\subsection{Cell lines}

The previously established murine microglial cell line BV2 [31] and the K562 erythroid cell line were maintained by biweekly passages in RPMI 1640 (Gibco, Grand Island, NY, USA), supplemented with $10 \%$ heat inactivated foetal bovine serum (Defined Hyclone, Logan, Utah, USA), $50 \mathrm{mg} / \mathrm{ml}$ gentamicin (EuroClone) and $2 \mathrm{mM}$ L-glutamine (EuroClone), hereafter referred to as complete medium. Experimental cultures were set at a concentration of $5 \times 10^{5}$ cells $/ \mathrm{ml}$ in complete medium on the day before each experiment.

\subsection{Biofilm formation}

Biofilm formation was obtained on 96-well culture plates, according to a previously described protocol [37] with minor modifications. Briefly, C. albicans yeast cells $\left(10^{5}\right.$ cells $\left./ \mathrm{ml}\right)$ were incubated at $37^{\circ} \mathrm{C}$ for $24 \mathrm{~h}$, in complete medium and in presence of $5 \% \mathrm{CO}_{2}$. Then, biofilm production was evaluated by crystal violet (CV) assay or 2,3-bis(2-methoxy-4-nitro-5-sulfophenyl)-2H-tetrazolium-5-carboxanilide (XTT, Sigma, St Louis, MO, USA) reduction assay, as detailed elsewhere [37]. For the CV assay, absorbance was measured spectrophotometrically by the SunRise Microplate Reader (Sunrise, Tecan, Salzburg, Austria) at $540 \mathrm{~nm}$ optical density $\left(\mathrm{OD}_{540}\right)$ and the colour intensity was proportional to biofilm biomass. For the XTT assay, the absorbance was measured spectrophotometrically at $450 \mathrm{~nm}$ with $620 \mathrm{~nm}$ as reference wavelength and the results, expressed as $\mathrm{OD}_{450 / 620}$, were correlated with cellular metabolic activities within the biofilm. Each sample was assessed in 6-replicates.

\subsection{Effects of microglial cells on C. albicans biofilm formation}

In order to assess the effects of microglial cells on biofilm formation, complete medium and BV2 cells $\left(10^{5}\right.$ cells $\left./ \mathrm{ml}\right)$ were added to $C$. albicans yeast cells that had been pre-incubated at $37^{\circ} \mathrm{C}$ in $5 \%$ $\mathrm{CO}_{2}$ for $3 \mathrm{~h}$. In parallel groups, $\mathrm{K} 562$ cells $\left(10^{5}\right.$ cells $\left./ \mathrm{ml}\right)$ were added as controls. Operationally, the $3 \mathrm{~h}$ pre-incubation was performed to allow fungal adhesion, as initial step in biofilm production. After additional 24 and $48 \mathrm{~h}$ incubation, microglial cells were lysed hypotonically, fungal biofilm formation (mass) and its metabolic 
activity were assessed by CV and XTT assays, respectively, in the presence or absence of BV2 and of K562 cells. Results were expressed as OD values (CV and XTT assays). Moreover, based on the literature [10], the percentage of fungal damage was calculated employing the data obtained with the XTT assay, according to the formula: $100 \times\left[1-\left(\mathrm{OD}_{\text {Candida }+\mathrm{BV} 2} / \mathrm{OD}_{\text {Candida alone }}\right)\right]$.

\subsection{Assessment of fungal gene expression}

C. albicans yeast cells $\left(10^{6}\right.$ cells $\left./ \mathrm{ml}\right)$ were pre-incubated in $25 \mathrm{ml}$ cell culture flasks in complete medium at $37{ }^{\circ} \mathrm{C}$, in presence of $5 \%$ $\mathrm{CO}_{2}$, for $3 \mathrm{~h}$. Then, BV2 cells $\left(10^{6}\right.$ cells $\left./ \mathrm{ml}\right)$ or complete medium were added and the flasks were further incubated. After $1 \mathrm{~h}$, microglial cells were lysed hypotonically and RNA was extracted using the TRIzol reagent (Invitrogen, CA, USA), according to manufacturer protocol. Then, purity and concentration of RNA extracts were measured by a NanoDrop 2000 Spectrophotometer (Thermo Fisher Scientific, Wilmington, DE, USA) and up to $2 \mathrm{ng}$ were retrotranscribed by the High Capacity RNA-to-cDNA Kit (Applied Biosystems, Foster City, CA, USA), in a final volume of $25 \mu \mathrm{l}$. Quantitative real-time PCR was performed in 48 well plates using the ABI StepOne apparatus (Applied Biosystems) and the Fast SYBR Green Master Mix (Applied Biosystems). Two primer sets were designed for the target gene HWP1 and the housekeeping gene inosine-5'-monophosphate dehydrogenase fragment (IMH3) using the Primer Express 2.0 software (Applied Biosystems); primer sequences were as follows:

HWP1 (5'-TGCTATCGCTTATTACATGTTATC-3', and 5'GAGCTTCTTCTGTTTCACCTTGAC-3');

IMH3 (5'-TATTCATATGGCATTATTGGGTGGTA- $3^{\prime}$, and 5'-AACCATTTCTGCTTGTTCTTCAGA-3').

The relative expression levels were calculated using the $2^{-\Delta \Delta \mathrm{Ct}}$ method. The control gene IMH3 was used to normalize the results.

\subsection{Cytokine measurement and nitric oxide determination}

Assays were performed as previously detailed [33]. Briefly, C. albicans yeast cells, $10^{5}$ cells/ml in 24 -well plates, were preincubated for $3 \mathrm{~h}$ in complete medium at $37{ }^{\circ} \mathrm{C}$ and in presence of $5 \% \mathrm{CO}_{2}$. Then, BV2 cells ( $10^{6}$ cells $\left./ \mathrm{ml}\right)$ or LPS $(1 \mu \mathrm{g} / \mathrm{ml}$, Sigma), the latter used as a positive control, were added to yeast cultures for additional 6 and $24 \mathrm{~h}$. Supernatants were then collected and assayed for TNF $\alpha$ content, by ELISA (R\&D Systems, Minneapolis, USA) according to manufacturer's recommendations. The reaction was read using the SunRise Microplate Reader $\left(O D_{450 / 540}\right)$. Each sample was run in triplicate and results were expressed as $\mathrm{pg} / \mathrm{ml}$ of cytokine. In parallel, the concentration of nitrite (NO) in the same supernatants was also measured using the Griess reagent, as previously described [33].

\subsection{Transmission electron microscopy (TEM)}

Samples for TEM analysis were processed as detailed elsewhere [38]. In particular, C. albicans yeast cells $\left(10^{6}\right.$ cells $\left./ \mathrm{ml}\right)$ were preincubated in 6 well plates in complete medium at $37{ }^{\circ} \mathrm{C}$, in presence of $5 \% \mathrm{CO}_{2}$, for $3 \mathrm{~h}$. Then, BV2 cells $\left(10^{6}\right.$ cells $\left./ \mathrm{ml}\right)$ or complete medium were added and incubation was carried out for further $24 \mathrm{~h}$. Then, monolayers were washed with PBS, scraped and centrifuged at $10,000 \times g$. The resulting pellets were fixed overnight with 2.5\% glutaraldehyde (Electron Microscopy Sciences, Hatfield, PA, USA) in Tyrode's buffer (Electron Microscopy Sciences), postfixed for $2 \mathrm{~h}$ in $1 \%$ osmium tetroxide (Electron Microscopy Sciences), dehydrated and embedded in Spurr resin (Electron Microscopy Sciences). Semi-thin sections, obtained through the whole thickness of the pellets, were stained with toluidine blue and observed with a Zeiss Axiophot (Carl Zeiss, Jena, Germany) light microscope. Ultrathin sections were stained with uranyl acetate and lead citrate and observed with a JEM 2010 (Jeol, Tokyo) transmission electron microscopy.

\subsection{Statistical analysis}

Statistical analysis was performed by the Student's t-test. Data in figures and table are expressed as mean or median values \pm standard deviation (SD) or standard error (SE) of three to five independent experiments, unless otherwise specified.

\section{Results}

\subsection{Biofilm production by the DAY286 (reference) and the FJS24 hwp1/hwp1 mutant strains}

To assess the involvement of the HWP1 genotype on biofilm production, two widely described laboratory strains $[13,16]$, the DAY286 (reference) and its hwp1/hwp1 mutant (FJS24), were investigated according to the protocols described in Materials and methods. Initially, the two strains were investigated for their ability to produce biofilm, according to previously established protocols [37]. As assessed by CV assay (Fig. 1), both strains achieved high and comparable levels of $\mathrm{OD}_{540}$ after $24 \mathrm{~h}$ in complete medium. Moreover, no significant changes/differences in $\mathrm{OD}_{540}$ levels were observed after $48 \mathrm{~h}$. Similar patterns of results, confirming no differences between the two strains, were also observed in parallel groups, as assessed by the XTT assay (data not shown).

\subsection{Impact of microglial cells on DAY286 (reference) and hwp1/ hwp1 mutant strains}

The impact of BV2 microglial cells on biofilm formation by the two laboratory strains was evaluated. Briefly, $C$. albicans yeast cells were pre-incubated for $3 \mathrm{~h}$ in complete medium; then, BV2 cells were added and the plates incubated for additional 24 or $48 \mathrm{~h}$. At each time point, the XTT assay was performed and the results were then expressed as percent of fungal damage by microglial cells, according to the established protocols [10]. As detailed in Fig. 2a, significant differences occurred between the two strains in terms of susceptibility to BV2 microglial cells; in particular, the null mutant showed levels of microglial cell-mediated damage significantly

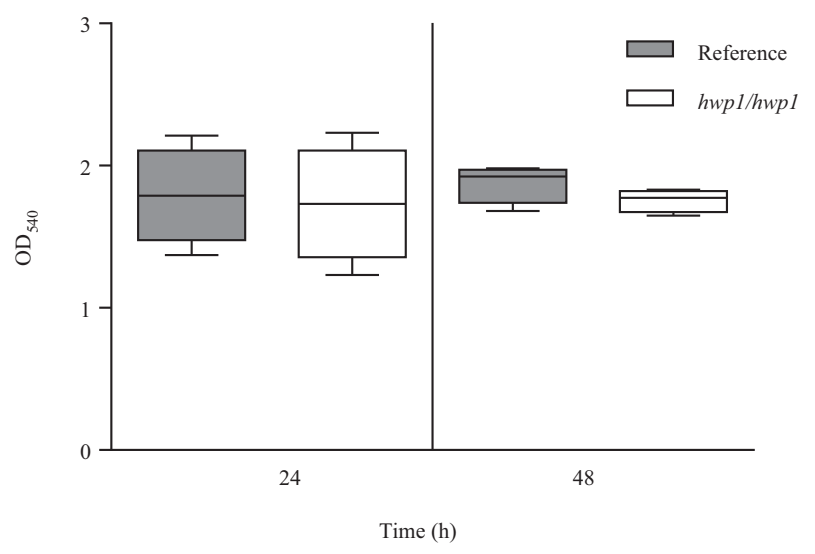

Fig. 1. Biofilm production by C. albicans strains DAY286 (reference) and hwp $1 / h w p 1$ (mutant). Yeast cells $\left(10^{5}\right.$ cells $\left./ \mathrm{ml}\right)$, were pre-incubated for $3 \mathrm{~h}$ (in complete medium and in $\left.5 \% \mathrm{CO}_{2}\right)$, then BV2 cells were added $\left(10^{6}\right.$ cells $\left./ \mathrm{ml}\right)$. After 24 and $48 \mathrm{~h}$ of incubation, CV assay was performed. Columns represent the range of $\mathrm{OD}_{540}$ values. SD are also shown. 

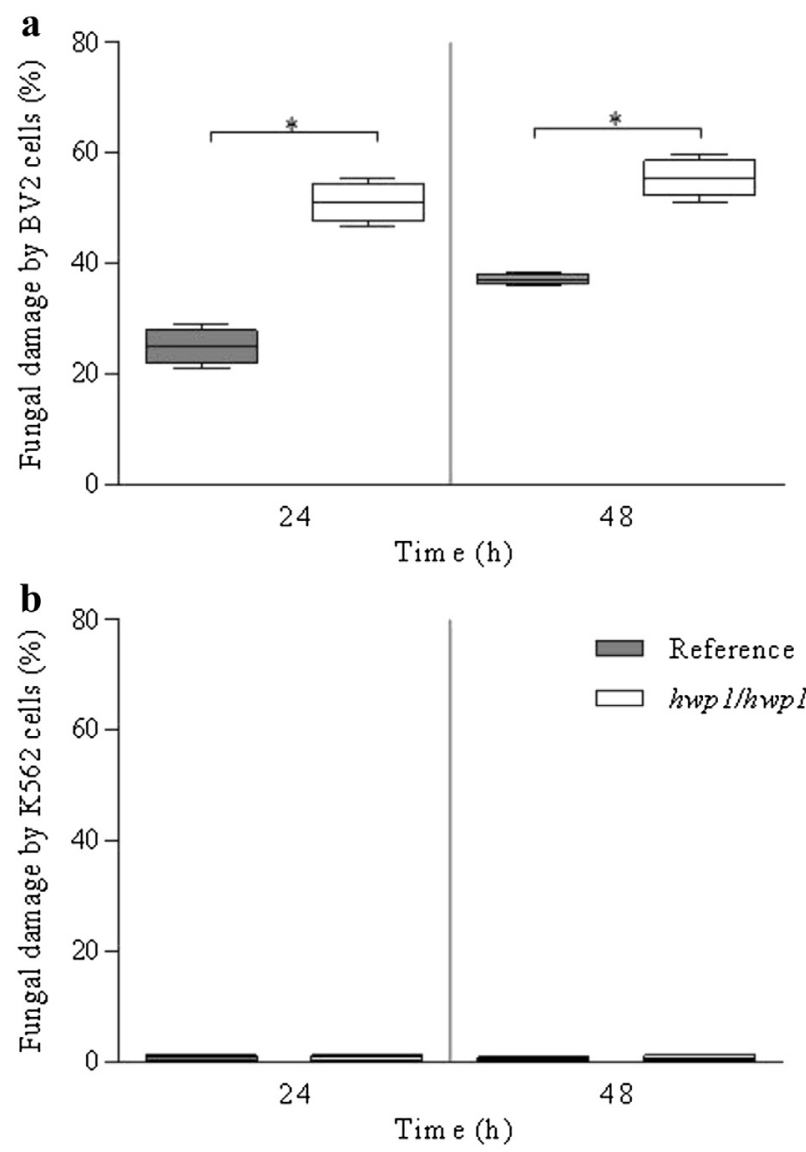

Fig. 2. Fungal damage induced by BV2 but no by K562 cells on C. albicans biofilm. Yeast cells $\left(10^{5}\right.$ cells $/ \mathrm{ml}$ ), were pre-incubated for $3 \mathrm{~h}$ (in complete medium and in presence of $\left.5 \% \mathrm{CO}_{2}\right)$, then medium or cells $\left(10^{6}\right.$ cells $\left./ \mathrm{ml}\right)$ were added. After 24 and $48 \mathrm{~h}$ of incubation, XTT assay was performed. Box-plots represent the percentage of fungal damage, calculated according to the formula reported in Materials and methods section, when Candida cells were exposed to BV2 (a) or to K562 cells (b). SD are also shown. Asterisks denote statistically significant difference, $\left({ }^{*}\right) p \leq 0.05$.

higher than the reference strain: $51 \%$ versus $24 \%$ at $24 \mathrm{~h}$ and $55 \%$ versus $37 \%$ at $48 \mathrm{~h}$, respectively. When in parallel groups, the nonimmuno-competent cell line K562 was included as negative control (Fig. 2b), no fungal damage was observed either at 24 or $48 \mathrm{~h}$ of incubation.

To further investigate the phenomenon, morphological analysis was performed. As detailed in Fig. 3, TEM images of Candida alone (incubated for $24 \mathrm{~h}$ in complete medium) revealed abundant and expanded adhesin-like structures on the surface of the DAY286 cells (Fig. 3a) but not on cells of the null mutant strain (Fig. 3b). Remarkable differences were also evident in terms of cell walls, which appeared loose and less compact in the null mutant strain with respect to the reference strain (see inserts in Fig. $3 a$ and b). Furthermore, as assessed by optical microscopy (Fig. 4), after $24 \mathrm{~h}$ of co-culture, microglial cells appeared profoundly damaged, irrespective of the contact with either DAY286 (Fig. 4a) or hwp1/hwp1 (Fig. 4b) Candida cells, while hyphal forms were more abundant in the DAY286 (Fig. 4a). In addition, large-size intracellular granules were especially evident in the reference strain (Fig. 4a vs b).

\subsection{Biofilm production by HWP1/HWP1 and HWP1/hwp1 clinical isolates and their susceptibility to microglial cells}

The C. albicans clinical isolates, three harbouring the HWP1/ HWP1 and three the HWP1/hwp1 genotypes, were compared for their capacity to form biofilm when grown in complete medium. As assessed by the XTT assay (Fig. 5a), the HWP1/HWP1 isolates displayed $\mathrm{OD}_{540}$ levels significantly higher than the HWP1/hwp1 counterparts $(p<0.05)$; the phenomenon was evident and consistent both at 24 and $48 \mathrm{~h}$; a similar trend of results was observed also by the CV assay (data not shown). Furthermore, the same $C$. albicans isolates were investigated for their susceptibility to microglial cells. Thus, $C$. albicans yeast cells were pre-incubated for $3 \mathrm{~h}$ in complete medium; then, microglial cells were added and the plates incubated for additional 24 or $48 \mathrm{~h}$. At each time point, the XTT assay was performed and the results were then expressed as percent of fungal damage by microglial cells. As detailed in Fig. 5b, fungal damage was significantly higher in the HWP1/hwp1 isolates than in the HWP1/HWP1 counterparts at both time points (54\% vs $26 \%$ at $24 \mathrm{~h}$ and $45 \%$ vs $20 \%$ at 48 h, respectively).

To better understand the interaction of the clinical isolates with the BV2 cells, these isolates were investigated by RT-PCR for the relative levels of $H W P 1$ gene expression in the presence and in the absence of microglial cells. Briefly, C. albicans yeast cells $\left(10^{6}\right.$ cells/ $\mathrm{ml}$ ) were pre-incubated for $3 \mathrm{~h}$ in complete medium. Then, complete medium or BV2 cells $\left(10^{6}\right.$ cells $\left./ \mathrm{ml}\right)$ were added and the cultures were further incubated for $1 \mathrm{~h}$. The relative levels of HWP1 gene expression are showed in Fig. 5c. A consistent up-regulation of HWP1 mRNA levels occurred in the group of HWP1/HWP1 isolates incubated in the presence of microglial cells compared to the control group (Candida alone). By contrast, HWP1/hwp1 isolates showed a limited though consistent down-regulation in the presence of microglial cells.

\subsection{Microglial cell secretory response to C. albicans laboratory strains and clinical isolates}

Finally, the profile of microglial cell secretory response to both laboratory strains and clinical isolates was investigated, according to previously established protocols $[10,33]$. Briefly, yeast cells were pre-incubated in complete medium for $3 \mathrm{~h}$; then, BV2 cells were added for additional 6 and $24 \mathrm{~h}$. In parallel groups, BV2 cells were exposed to LPS, used as positive control. Supernatants were harvested and assessed for TNF $\alpha$ and NO content. Table 1 shows TNF $\alpha$ and NO production by BV2 cells exposed to the two laboratory strains, the DAY286 and the mutant FJS24, and two clinical isolates, Ca50vr and Ca24ba, representative of the HWP1/HWP1 and HWP1/ hwp1 genotypes, respectively. As expected, LPS greatly enhanced TNF $\alpha$ production by BV2 cells, with maximal levels being reached at $6 \mathrm{~h}$. A time-dependent production of TNF $\alpha$ was also observed in BV2 cells exposed to Candida isolates. In particular, both DAY286 and Ca50vr (HWP1/HWP1) induced levels of TNF $\alpha$ significantly higher than their counterparts, the mutant FJS24 and Ca24ba (HWP1/hwp1). Concerning NO production, a significant increase occurred, at $24 \mathrm{~h}$, only in BV2 cells exposed to DAY286 and Ca50vr (HWP1/HWP1).

\section{Discussion}

Here, by means of laboratory isogenic strains and clinical isolates, we show that $C$. albicans HWP1 genotype does not affect biofilm formation in vitro, but rather it influences fungal susceptibility to microglial cells.

Increasing literature is being provided on fungal genetic traits that are possibly involved in biofilm formation and virulence [13,15-17]; construction of laboratory mutant strains as well as genotyping of clinical isolates has allowed direct associations between certain phenotypic peculiarities/functions and specific genotypic elements $[19,20]$. In particular, the HWP1 gene appears to be involved in several pathogenic steps, including adherence to 

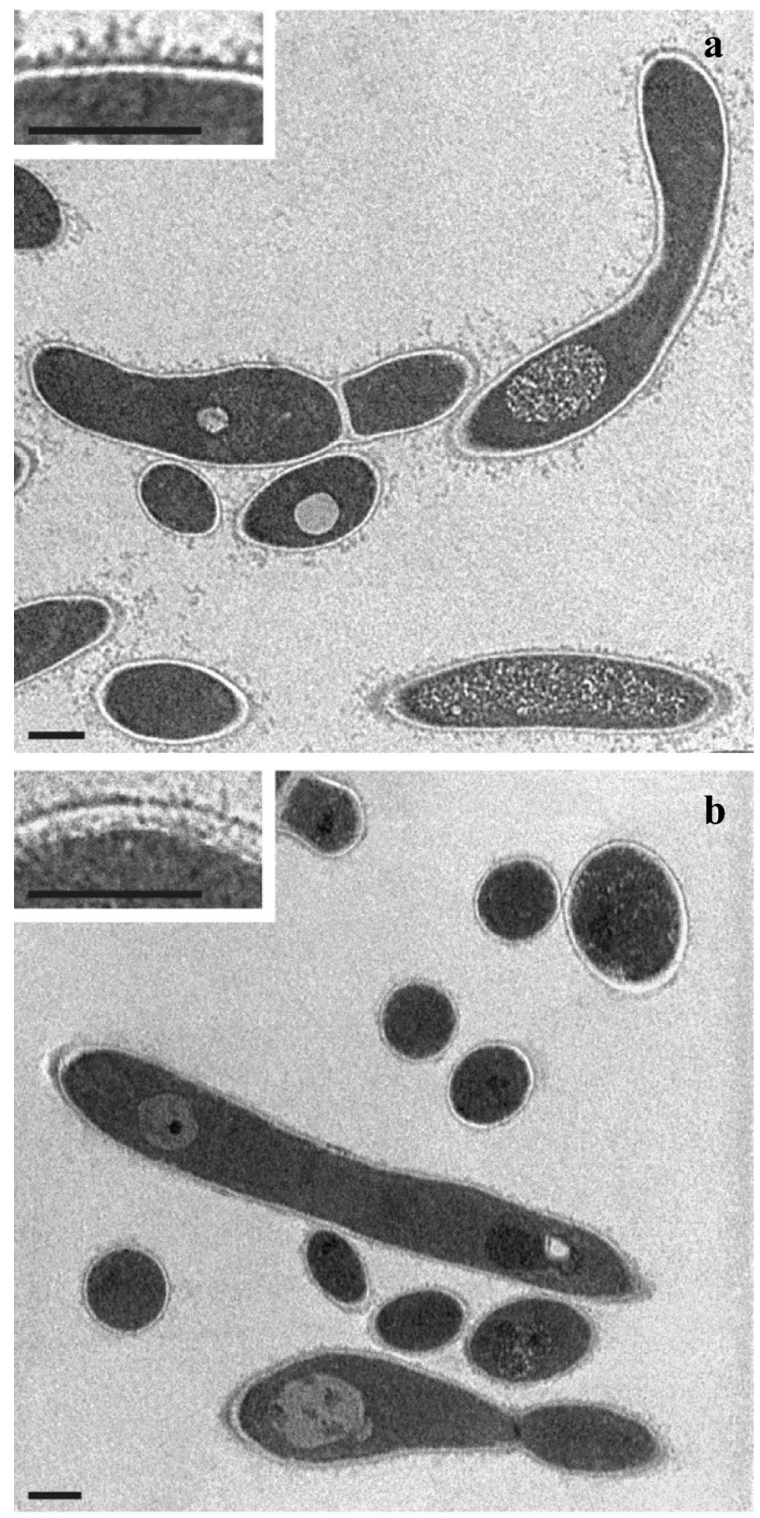

Fig. 3. Ultrastructural morphology of C. albicans strains DAY286 (reference) and hwp $1 /$ hwp 1 (mutant). Yeast cells $\left(10^{6}\right.$ cells $\left./ \mathrm{ml}\right)$, incubated for $24 \mathrm{~h}$ (in complete medium and in presence of $5 \% \mathrm{CO}_{2}$ ), were fixed and embedded in resin to allow observation of ultrathin sections by TEM. Representative image of (a) DAY286 reference strain and (b) hwp1/hwp1 mutant strain. Bar $=1 \mu \mathrm{m}$.

epithelial cells and virulence in mice [19-22,24,25]. Recently, by a National Survey Study on invasive fungal infections, we obtained and partially characterized a collection of 142 clinical C. albicans isolates, whose profiles of HWP1 genotype, biofilm production and antifungal drug susceptibility have been investigated [35]. Also, initial information has been provided on the relationship between ability to produce biofilm in vitro and virulence in Galleria mellonella [11]. With the aim of more in depth investigating the role of HWP1 genotype on biofilm formation, the present study has been conducted employing i) two laboratory strains, the reference C. albicans DAY286 strain and its HWP1 null mutant FJS24, and ii) six clinical isolates, harbouring the HWP1/HWP1 and the HWP1/hwp1 genotype. Preliminarily, Candida strains/isolates have been compared for their growth rate under different conditions, namely at different yeast cell concentrations and in the presence of complete medium or YPD, over a 48-h incubation period. As detailed in
Supplementary Table S1, although the growth rates appear different in complete medium or YPD, yet, no statistically significant differences have been observed when comparing the DAY286 with its mutant FJS24 or the Ca50vr HWP1/HWP1 with the Ca24ba HWP1/hwp1 clinical isolates. As detailed in Fig. 1, the two laboratory strains produce biofilm to a similar extent, while differences are evident between HWP1/HWP1 and HWP1/hwp1 clinical isolates, with the latter being lower biofilm producers (Fig. 5a). In line with these data, Tsuchimori and coworkers [25] have recently shown that also other sets of engineered strains, differing in HWP1 genotype, exhibit similar propensities to produce biofilm. In contrast, our results on clinical isolates reveal differences in biofilm formation between the two groups, operationally clustered in this study according to their HWP1 genotype. The unexpected discrepancy observed with the clinical isolates raises the possibility that additional unexplored genotypic differences between homo- and heterozygous HWP1 isolates may be responsible for the different behaviour, at least in terms of biofilm production. Possibly, a complete genotypic characterization of the clinical isolates may
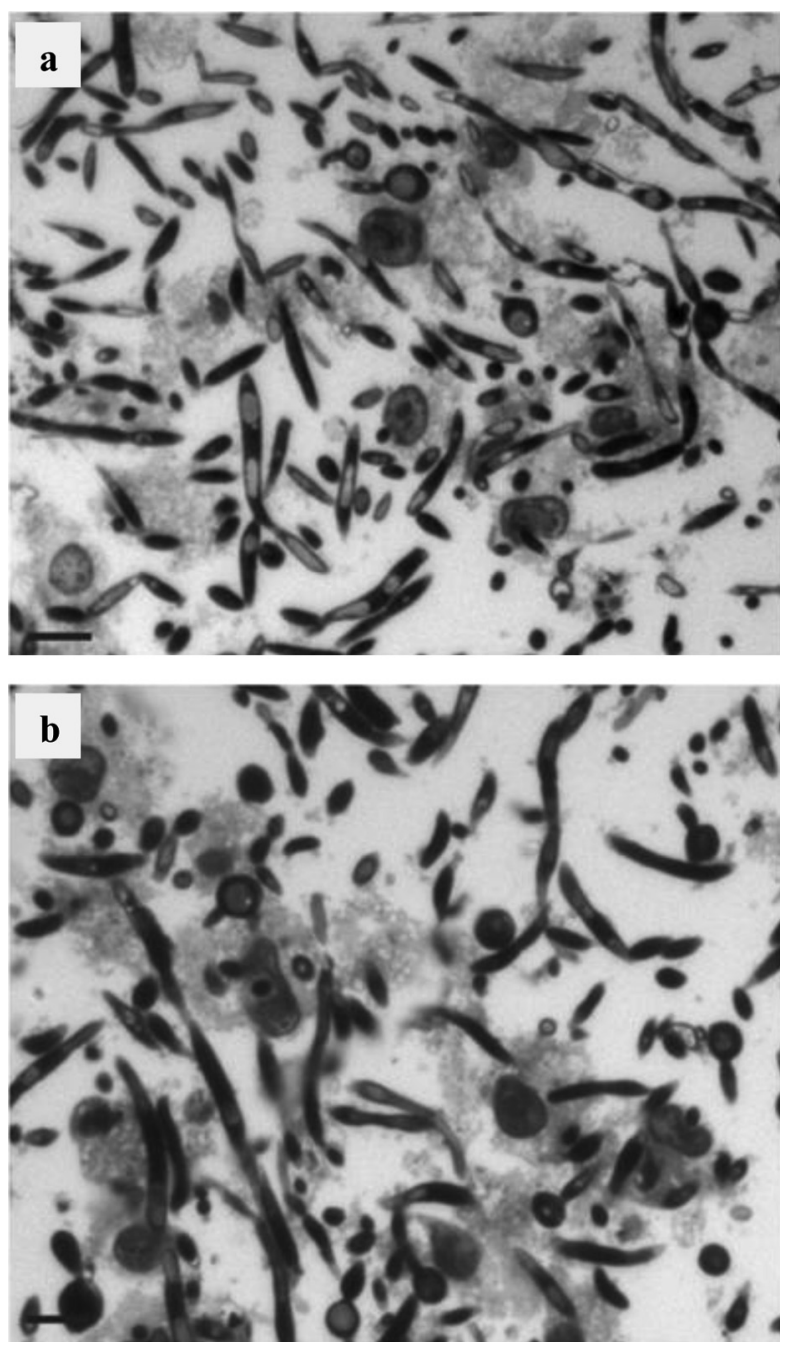

Fig. 4. Morphology of 24 h-old Candida-microglial cells co-cultures. C. albicans DAY286 (reference) and FJS24 (hwp1/hwp1 mutant), at the $10^{6}$ cells/ml cell density, were preincubated for $3 \mathrm{~h}$ (in complete medium and in $5 \% \mathrm{CO}_{2}$ ), then $\mathrm{BV} 2$ cells were added $\left(10^{6}\right.$ cells $\left./ \mathrm{ml}\right)$. After $24 \mathrm{~h}$ of incubation, samples were fixed and embedded in resin. Semi-thin sections were examined by light microscopy. Representative images of (a) DAY286 reference strain and (b) hwp1/hwp1 FJS24 mutant strains, both exposed to BV2 cells. Bar $=10 \mu \mathrm{m}$. 

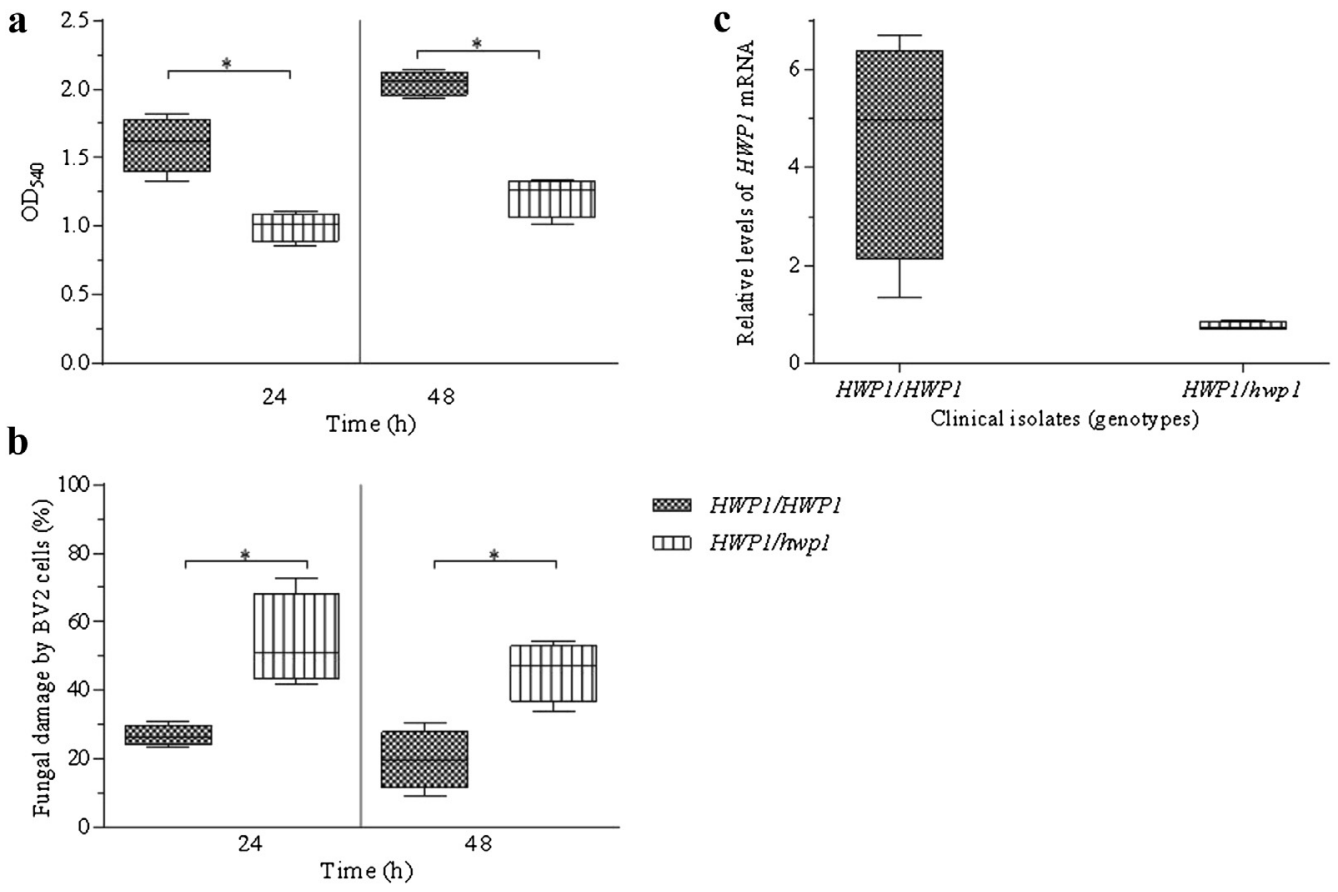

HWPI/HWPI

HWPl/hwpl

Fig. 5. Biofilm production by C. albicans clinical isolates and their susceptibility to microglial cells. Three HWP1/HWP1 and 3 HWP1/hwp1 isolates were assessed. Biofilm production (a) by yeast cells $\left(10^{5}\right.$ cells $\left./ \mathrm{ml}\right)$ incubated for 24 and $48 \mathrm{~h}$, in complete medium, was evaluated by $\mathrm{CV}$ assay. Box-plots represent the range of OD $\mathrm{D}_{540}$ values. For the evaluation of fungal susceptibility to BV2 cell, yeast cells $\left(10^{5}\right.$ cells $\left./ \mathrm{ml}\right)$ were pre-incubated for $3 \mathrm{~h}$ (in complete medium), then complete medium or BV2 cells were added $\left(10^{6}\right.$ cells/ml) for 1,24 or $48 \mathrm{~h}$. After 24 and $48 \mathrm{~h}$ of incubation, XTT assay was performed and box-plots represent the percentage of fungal damage (b), calculated according to the formula detailed in Materials and methods section. In parallel, after $1 \mathrm{~h}$ of incubation, yeast RNA was extracted and HWP1 gene expression was evaluated by RT-PCR (c). Box-plots represent the relative levels of HWP1 mRNA expression. Mean values and SD are also shown. Asterisks denote statistically significant differences, $\left({ }^{*}\right) p \leq 0.05$.

provide clear-cut information on this matter. At the moment, based on previous [25] and present findings, we favour the conclusion that HWP1 genotype does not directly affect Candida ability to produce biofilm in vitro.

Previous studies demonstrate that microglial cells efficiently contrast $C$. albicans by phagocytosis and killing of the yeast cells $[26,28,33]$. Here, we show that such immune cells are also capable of affecting fungal biofilm and that the extent of such phenomenon is related to Candida HWP1 genotype; interestingly, the impact of microglial cells on biofilm production is similar, both in clinical isolates and laboratory strains. In particular, when exposed to microglial cells for $24 \mathrm{~h}$, both the engineered hwp1/hwp 1 mutant strain (Fig. 2a) and the heterozygous clinical HWP1/hwp1 isolates (Fig. 5b) are damaged to a higher extent than their HWP1/HWP1 counterparts; such differential profiles of susceptibility are retained also at later times ( $48 \mathrm{~h}$ ), when the null mutant (Fig. 2a) and the heterozygous (Fig. 5b) are still significantly affected, while the homozygous, HWP1/HWP1, are no longer susceptible to microglial cell-mediated damage. Interestingly, non immuno-competent cells, such as the erythroid cell line K562, fail to exert any deleterious effect on fungal biofilm production (Fig. 2b), thus further strengthening the direct role of BV2 cells while other trivial events such as nutrient limitation or steric cell-to-cell interference may be ruled out. Overall, by assessing different parameters, namely fungal biomass and metabolic activity, the CV and XTT assays unanimously indicate that Candida biofilm production is significantly impaired by microglial cells. Our present findings are in line with a previous study demonstrating that phagocytes can induce biofilm damage

Table 1

TNF $\alpha$ and NO production by BV2 microglial cells exposed to laboratory strains and clinical isolates for 6 and $24 \mathrm{~h}$.

\begin{tabular}{|c|c|c|c|c|c|}
\hline \multirow[t]{2}{*}{ BV2 cell exposure to: } & \multicolumn{2}{|c|}{$\mathrm{TNF} \alpha(\mathrm{pg} / \mathrm{ml})$} & & \multicolumn{2}{|c|}{ NO $(\mu \mathrm{M})$} \\
\hline & $6 \mathrm{~h}$ & $24 \mathrm{~h}$ & & $6 \mathrm{~h}$ & $24 \mathrm{~h}$ \\
\hline Medium & 23,40 & 23,40 & & 3,00 & 3,39 \\
\hline LPS $(1 \mu \mathrm{g} / \mathrm{ml})$ & 5360,00 & 4685,10 & & 3,39 & 8,93 \\
\hline DAY286 & 299,01 & 340,56 & & 4,62 & 13,20 \\
\hline FJS24 (hwpl/hwpl) & 220,12 & 223,22 & $*$ & 4,60 & 4,60 \\
\hline Ca50vr $(H W P 1 / H W P 1)$ & 297,49 & 334,31 & * & 4,62 & 13,53 \\
\hline $\mathrm{Ca} 24 \mathrm{ba}(H W P 1 / h w p l)$ & 223,85 & 231,21 & & 4,62 & 4,62 \\
\hline
\end{tabular}

Candida yeast cells $\left(10^{5} \mathrm{cell} / \mathrm{ml}\right)$ were pre-incubated in complete medium for $3 \mathrm{~h}$; then complete medium or BV2 cells were added and the plates were incubated for additional 6 or $24 \mathrm{~h}$. TNF $\alpha$ and NO were subsequently measured in the cell-free supernatants, as detailed above. SD values were always less than $5 \%$ and therefore they have been omitted. $* \mathrm{p} \leq 0.001$. 
[10]. By contrast, it has been shown that human peripheral blood mononuclear cells may enhance the ability of $C$. albicans to form biofilm [39]. Differences in the experimental protocols employed (timing, cultural conditions, etc.) and in the immune cell types investigated may account for the apparent disagreement among studies aimed at defining the role of phagocytes on fungal biofilm production.

Here, as assessed by the clinical isolates, only the homozygous genotypes show a significant enhancement of HWP1 mRNA levels, following Candida exposure to the microglial cells (Fig. 5c). Besides indicating a different Candida behaviour based on its HWP1 genotype, these data also imply the capacity of Candida to re-program its own molecular machinery in response to the insult provided by the immune cells, at least in terms of HWP1 transcript levels, thus further supporting the idea that HWP1 should be considered as a virulence trait. In line with this conclusion, Staab and coworkers [18] provide initial evidence on the relevance of HWP1 genotype on Candida adhesion to epithelial cells in vitro.

Concerning the secretory response of microglial cells to C. albicans, enhanced TNF $\alpha$ and NO production occurs when employing the homozygous HWP1/HWP1 genotypes, both of laboratory and clinical origin, while little or no response is observed against the heterozygous or null mutant counterpart (Table 1). In line with our previous work [32], we show that C. albicans promotes an enhanced secretory response by microglial cells.

Whether structural or rather pathogenetic changes are involved, in such a microglial cell-related response, remains to be investigated. In any case, the present data provide the first evidence that microglial cells secretory response is differently modulated, depending upon Candida HWP1 genotype.

Finally, morphological analysis reveals several differences between the HWP1/HWP1 and hwp1/hwp1 Candida cells. In particular, the former express abundant adhesin-like structures, barely detectable in the null mutant, within which both cell wall consistency and thickness appear altered (Fig. 3). While expanding previous morphological data $[24,40]$, these findings emphasize the dual role of HWP1 protein, both as a surface adhesion molecule and as a protein important in maintaining cell wall integrity. Moreover, here we show that upon Candida-microglial cell co-culture, the $h w p 1 / h w p 1$ fungal bodies appear not only less numerous but also they show reduced intracellular granules (Fig. 4); to our opinion, such features can be reasonably explained as markers of microglial cell-induced stress/damage. Thus, taken together, the morphological peculiarities and the quantitative data obtained by XTT and CV assays underline the enhanced susceptibility of the null mutant to microglial cells.

Initial efforts are being made in dissecting the pathogenic role of HWP1 in candidiasis. By a murine model of oro-esophageal candidiasis, HWP1 genotype has been associated with a peculiar pathogen-mucosal cell interplay [19,41], while HWP1 ablation has resulted in reduced virulence, as assessed by a systemic candidiasis model $[25,42]$. Here, we provide in vitro evidence that HWP1 genotype does not directly influence Candida ability to produce biofilm, but it significantly affects microglial cell-mediated efficacy. Thus, we may envisage in vivo situations where Candida HWP1 genotype plays a pathogenetic role as soon as the first line immune defences are called up as critical defence players.

\section{Author contributions}

Conceived and designed the experiments: CFO RGN EB. Performed the experiments: CFO EB BC DQ. Analyzed the data: CFO EB AA. Contributed reagents/materials/analysis tools: GM EB. Wrote the paper: CFO EB AA.

\section{Acknowledgements}

The present study was partially supported by a grant to EB from the MIUR (Italy) Project, PRIN-200985J87J.

\section{Appendix A. Supplementary data}

Supplementary data related to this article can be found at http:// dx.doi.org/10.1016/j.micpath.2014.03.003.

\section{References}

[1] Pfaller MA, Diekema DJ. Epidemiology of invasive candidiasis: a persistent public health problem. Clin Microbiol Rev 2007;20:133-63. http://dx.doi.org/ 10.1038 /nport.2008.141.

[2] Gullo A. Invasive fungal infections: the challenge continues. Drugs 2009;69: 65-73. http://dx.doi.org/10.2165/11315530-000000000-00000.

[3] Cahan H, Deville JG. Outcomes of neonatal candidiasis: the impact of delayed initiation of antifungal therapy. Int J Pediatr 2011;2011:813871. http:// dx.doi.org/10.1155/2011/813871.

[4] Ramage G, Martínez JP, López-Ribot JL. Candida biofilms on implanted biomaterials: a clinically significant problem. FEMS Yeast Res 2006;6:979-86. http://dx.doi.org/10.1111/j.1567-1364.2006.00117.x.

[5] Wenzel RP, Edmond MB. The evolving technology of venous access. N Engl J Med 1999;340:48-50. http://dx.doi.org/10.1056/NEJM199901073400109.

[6] Kojic EM, Darouiche RO. Candida infections of medical devices. Clin Microbiol Rev 2004;17:255-67.

[7] Sánchez-Portocarrero J, Martín-Rabadán P, Saldaña CJ, Pérez-Cecilia E. Candida cerebrospinal fluid shunt infection. Report of two new cases and review of the literature. Diagn Microbiol Infect Dis 1994;20:33-40.

[8] Ramage G, Saville SP, Thomas DP, López-Ribot JL. Candida biofilms: an update. Eukaryot Cell 2005;4:633-8. http://dx.doi.org/10.1128/EC.4.4.633-638.2005.

[9] Kumamoto CA, Vinces MD. Alternative Candida albicans lifestyles: growth on surfaces. Annu Rev Microbiol 2005;59:113-33. http://dx.doi.org/10.1146/ annurev.micro.59.030804.121034.

[10] Katragkou A, Kruhlak MJ, Simitsopoulou M, Chatzimoschou A, Taparkou A, Cotten $\mathrm{CJ}$, et al. Interactions between human phagocytes and Candida albicans biofilms alone and in combination with antifungal agents. J Infect Dis 2010;201:1941-9. http://dx.doi.org/10.1086/652783.

[11] Cirasola D, Sciota R, Vizzini L, Ricucci V, Morace G, Borghi E. Experimental biofilm-related Candida infections. Future Microbiol 2013;8:799-805. http:// dx.doi.org/10.2217/fmb.13.36.

[12] Mazaheritehrani E, Sala A, Orsi CF, Neglia RG, Morace G, Blasi E, et al. Human pathogenic viruses are retained in and released by Candida albicans biofilm in vitro. Virus Res 2014;179:153-60. http://dx.doi.org/10.1016/ j.virusres.2013.10.018.

[13] Nobile CJ, Mitchell AP. Regulation of cell-surface genes and biofilm formation by the C. albicans transcription factor Bcr1p. Curr Biol CB 2005;15:1150-5. http://dx.doi.org/10.1016/j.cub.2005.05.047.

[14] Thomas DP, Bachmann SP, Lopez-Ribot JL. Proteomics for the analysis of the Candida albicans biofilm lifestyle. Proteomics 2006;6:5795-804. http:// dx.doi.org/10.1002/pmic.200600332.

[15] Harriott MM, Lilly EA, Rodriguez TE, Fidel Jr PL, Noverr MC. Candida albicans forms biofilms on the vaginal mucosa. Microbiol Read Engl 2010;156:363544. http://dx.doi.org/10.1099/mic.0.039354-0.

[16] Nobile CJ, Andes DR, Nett JE, Smith FJ, Yue F, Phan Q-T, et al. Critical role of Bcr1-dependent adhesins in C. albicans biofilm formation in vitro and in vivo. PLoS Pathog 2006;2:e63. http://dx.doi.org/10.1371/journal.ppat.0020063.

[17] Nobile CJ, Nett JE, Andes DR, Mitchell AP. Function of Candida albicans adhesin Hwp1 in biofilm formation. Eukaryot Cell 2006;5:1604-10. http://dx.doi.org/ 10.1128/EC.00194-06.

[18] Staab JF, Bradway SD, Fidel PL, Sundstrom P. Adhesive and mammalian transglutaminase substrate properties of Candida albicans Hwp1. Science 1999;283:1535-8.

[19] Sundstrom P, Balish E, Allen CM. Essential role of the Candida albicans transglutaminase substrate, hyphal wall protein 1 , in lethal oroesophageal candidiasis in immunodeficient mice. J Infect Dis 2002;185:521-30. http:// dx.doi.org/10.1086/338836.

[20] Naglik JR, Fostira F, Ruprai J, Staab JF, Challacombe SJ, Sundstrom P. Candida albicans HWP1 gene expression and host antibody responses in colonization and disease. J Med Microbiol 2006;55:1323-7. http://dx.doi.org/10.1099/ jmm.0.46737-0.

[21] Biswas S, Van Dijck P, Datta A. Environmental sensing and signal transduction pathways regulating morphopathogenic determinants of Candida albicans. Microbiol Mol Biol Rev 2007;71:348-76. http://dx.doi.org/10.1128/ MMBR.00009-06.

[22] Chaffin WL. Candida albicans cell wall proteins. Microbiol Mol Biol Rev MMBR 2008;72:495-544. http://dx.doi.org/10.1128/MMBR.00032-07.

[23] Finkel JS, Mitchell AP. Genetic control of Candida albicans biofilm development. Nat Rev Microbiol Feb 2011;9(2):109-18. http://dx.doi.org/10.1038/ nrmicro2475. 
[24] de Groot PWJ, Bader O, de Boer AD, Weig M, Chauhan N. Adhesins in human fungal pathogens: glue with plenty of stick. Eukaryot Cell 2013;12:470-81. http://dx.doi.org/10.1128/EC.00364-12.

[25] Tsuchimori N, Sharkey LL, Fonzi WA, French SW, Edwards Jr JE, Filler SG. Reduced virulence of HWP1-deficient mutants of Candida albicans and their interactions with host cells. Infect Immun 2000;68:1997-2002.

[26] Blasi E, Mazzolla R, Pitzurra L, Barluzzi R, Bistoni F. Protective effect of picolinic acid on mice intracerebrally infected with lethal doses of Candida albicans. Antimicrob Agents Chemother 1993:37:2422-6.

[27] Blasi E, Pitzurra L, Puliti M, Mazzolla R, Barluzzi R, Saleppico S, et al. Different events involved in the induction of macrophage tumor necrosis factor by Candida albicans and lipopolysaccharide. Cell Immunol 1994;157:501-9. http://dx.doi.org/10.1006/cimm.1994.1245.

[28] Blasi E, Mazzolla R, Barluzzi R, Bistoni F. Microglial cell-mediated anti-Candida activity: temperature, ions, protein kinase $\mathrm{C}$ as crucial elements. J Neuroimmunol 1991;34:53-60.

[29] Blasi E, Mucci A, Neglia R, Pezzini F, Colombari B, Radzioch D, et al. Biological importance of the two Toll-like receptors, TLR2 and TLR4, in macrophage response to infection with Candida albicans. FEMS Immunol Med Microbio 2005;44:69-79.

[30] Puliti M, Radzioch D, Mazzolla R, Barluzzi R, Bistoni F, Blasi E. Influence of the Bcg locus on macrophage response to the dimorphic fungus Candida albicans. Infect Immun 1995;63:4170-3.

[31] Blasi E, Barluzzi R, Bocchini V, Mazzolla R, Bistoni F. Immortalization of murine microglial cells by a v-raf/v-myc carrying retrovirus. J Neuroimmunol $1990 ; 27: 229-37$.

[32] Blasi E, Pitzurra L, Puliti M, Lanfrancone L, Bistoni F. Early differential molecular response of a macrophage cell line to yeast and hyphal forms of Candida albicans. Infect Immun 1992;60:832-7.

[33] Neglia R, Colombari B, Peppoloni S, Orsi C, Tavanti A, Senesi S, et al. Adaptive response of microglial cells to in vitro infection by Candida albicans isolates with different genomic backgrounds. Microb Pathog 2006;41:251-6. http:// dx.doi.org/10.1016/j.micpath.2006.08.001.

[34] McCluskey K. The fungal genetics stock Center: from molds to molecules. Adv Appl Microbiol 2003;52:245-62.
[35] Morace G, Borghi E, Iatta R, Amato G, Andreoni S, Brigante G, et al. Antifungal susceptibility of invasive yeast isolates in Italy: the GISIA3 study in critically ill patients. BMC Infect Dis 2011;11:130. http://dx.doi.org/10.1186/1471-233411-130.

[36] Padovan ACB, Chaves GM, Colombo AL, Briones MRS. A novel allele of HWP1, isolated from a clinical strain of Candida albicans with defective hyphal growth and biofilm formation, has deletions of Gln/Pro and Ser/Thr repeats involved in cellular adhesion. Med Mycol Off Publ Int Soc Hum Anim Mycol 2009;47:824-35. http://dx.doi.org/10.3109/13693780802669574.

[37] Pierce CG, Uppuluri P, Tristan AR, Wormley Jr FL, Mowat E, Ramage G, et al. A simple and reproducible 96 -well plate-based method for the formation of fungal biofilms and its application to antifungal susceptibility testing. Nat Protoc 2008;3:1494-500. http://dx.doi.org/10.1038/nport.2008.141.

[38] Quaglino D, Ha HR, Duner E, Bruttomesso D, Bigler L, Follath F, et al. Effects of metabolites and analogs of amiodarone on alveolar macrophages: structureactivity relationship. Am J Physiol Lung Cell Mol Physiol 2004;287:L438-47. http://dx.doi.org/10.1152/ajplung.00434.2003.

[39] Chandra J, McCormick TS, Imamura Y, Mukherjee PK, Ghannoum MA. Interaction of Candida albicans with adherent human peripheral blood mononuclear cells increases $C$. albicans biofilm formation and results in differential expression of pro- and anti-inflammatory cytokines. Infect Immun 2007;75: 2612-20. http://dx.doi.org/10.1128/IAI.01841-06.

[40] Plaine A, Walker L, Da Costa G, Mora-Montes HM, McKinnon A, Gow NAR, et al. Functional analysis of Candida albicans GPI-anchored proteins: roles in cell wall integrity and caspofungin sensitivity. Fungal Genet Biol 2008;45: 1404-14. http://dx.doi.org/10.1016/j.fgb.2008.08.003.

[41] Balish E, Warner T, Pierson CJ, Bock DM, Wagner RD. Oroesophageal candidiasis is lethal for transgenic mice with combined natural killer and T-cell defects. Med Mycol Off Publ Int Soc Hum Anim Mycol 2001;39:261-8.

[42] Sundstrom P, Cutler JE, Staab JF. Reevaluation of the role of HWP1 in systemic candidiasis by use of Candida albicans strains with selectable marker URA3 targeted to the ENO1 locus. Infect Immun 2002;70:3281-3. http://dx.doi.org/ $10.1086 / 338836$ 